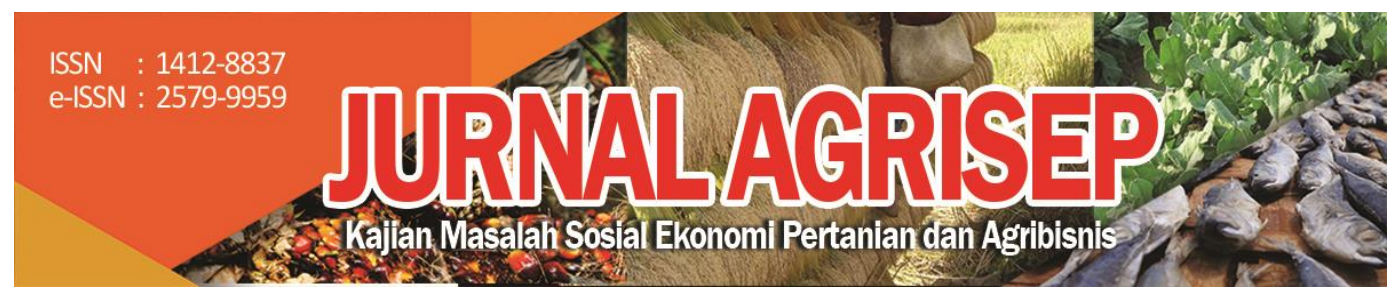

DOI: 10.31186/jagrisep.20.1.81-94

\title{
PENGETAHUAN DAN PERSEPSI PETANI TERHADAP PENGOMPOSAN LIMBAH JERAMI PADI
}

\author{
Knowledge and Perception of Farmers Towards Composting Rice Straw \\ Waste \\ I Nengah Muliarta \\ Program Studi Agroekoteknolgi, Universitas Warmadewa, Denpasar-Bali \\ Email: nengahmuliarta@gmail.com
}

\begin{abstract}
The utilization of rice straw as compost is very related to farmers' knowledge on how to compost agricultural waste. Knowledge of rice straw composting owned by farmers is closely related to socialization and training obtained from field extension officers (FEO). The role of FEO in the field becomes very strategic in an effort to increase farmers' knowledge about agricultural waste treatment and its utilization so as to provide economic impact. The purpose of the research is to understand the knowledge and perception of farmers about composting rice straw. By using survey and interview methods, this research also seeks to uncover farmers' knowledge related to rice straw compost. The research was conducted in 3 sub-districts in Klungkung (Klungkung, Dawan, and Banjarangkan) during May-June 2017. The results showed that farmers do not know how to compost rice straw because only $2.25 \%$ of farmers have ever attended rice straw composting training. Dominant farmers $(74.16 \%)$ view if rice straw cannot be composted. The results of interviews with FEO in the Klungkung district obtained the fact that FEO never socialized rice straw composting.
\end{abstract}

Keywords: Knowledge, Perception, Farmer, Composting, Rice Straw.

\section{ABSTRAK}

Pemanfaatan jerami padi sebagai kompos sangat berkaitan dengan pengetahuan petani terhadap cara pengomposan limbah pertanian tersebut. Pengetahuan pengomposan jerami padi yang dimiliki petani erat kaitannya dengan sosialisasi dan pelatihan yang didapatkan dari petugas penyuluh lapangan (PPL). Peran PPL di lapangan menjadi sangat strategis dalam upaya meningkatkan pengetahuan petani 
mengenai pengolahan limbah pertanian dan pemanfaatanya sehingga memberikan dampak ekonomi. Tujuan penelitian yaitu memahami pengetahuan dan persepsi petani mengenai pengomposan jerami padi. Dengan menggunakan metode survey dan wawancara, penelitian ini juga berusaha mengungkap pengetahuan petani terkait kompos jerami padi. Penelitian dilakukan di 3 kecamatan di Klungkung (Klungkung, Dawan dan Banjarangkan) selama Mei-Juni 2017. Hasil penelitian menunjukkan bahwa petani tidak mengetahui cara pengomposan jerami padi, karena hanya 2,25\% petani yang pernah mengikuti pelatihan pengomposan jerami padi. Dominan petani $(74,16 \%)$ berpandangan jika jerami padi tidak dapat dikomposkan. Hasil wawancara dengan PPL di Kabupaten Klungkung mendapatkan fakta bahwa, PPL tidak pernah melakukan sosialisasi pengomposan jerami padi.

Kata kunci: Pengetahuan, Persepsi, Petani, Pengomposan, Jerami Padi.

\section{PENDAHULUAN}

Praktek pembakaran jerami secara terbuka telah terbukti menjadi sumber emisi karbon yang signifikan selama musim panen. Pembakaran jerami secara terbuka secara signifikan juga telah mempengaruhi kualitas udara (Chang et al., 2013). Pembakaran jerami padi tidak saja menyebabkan polusi udara, tetapi juga berdampak pada kesehatan masyarakat dan perubahan iklim (Tipayarom \& Oanh, 2007).

Jerami padi termasuk bahan baku lokal yang dapat dimanfaatkan dan diolah menjadi pupuk organik. Ketersediaannya saat panen sangat berlimpah, namun selama ini belum dimanfaatkan secara optimal (Zhao et al., 2015). Secara global diperkirakan jumlahnya mencapai 650-975 juta ton per-tahun. Dalam setiap $1 \mathrm{~kg}$ gabah dihasilkan 1-1,5 kg jerami padi (Binod et al., 2010).

Jerami padi merupakan limbah pertanian yang mengandung unsur hara yang berguna untuk menjaga kestabilan unsur hara tanah dan untuk memenuhi kebutuhan hara tanaman (Pavithira et al., 2017). Jerami padi mengandung sekitar $40 \%$ unsur N, 30 sampai $35 \%$ dari $\mathrm{P}, 80-85 \%$ unsur K, dan $40-45 \%$ unsur S yang diambil tanaman padi dari tanah (Dobermann \& Fairhurst, 2002). Pemanfaatannya menjadi kompos tidak hanya menyediakan nutrisi penting bagi tanaman, tetapi menjadi upaya menjaga kelestarian lingkungan melalui pengelolaan limbah (Golabi et al., 2004). Kenyataanya di lapangan tidak banyak petani yang memanfaatkan atau mengolah jerami menjadi kompos. Apabila tidak terdapat upaya untuk melakukan daur ulang limbah pertanian akan berdampak pada terjadinya degradasi lahan pertanian (Afriani et al., 2013).

Kompos merupakan sumber bahan organik yang dihasilkan dari pemanfaatan limbah melalui proses biokonversi secara terkendali (Rashad et al., 2011). Kompos berguna dalam memperbaiki kesuburan tanah, karena berdampak pada perubahan sifat fisik, biologi dan kimia tanah. Kompos jerami padi dan pemanfaatanmya pada tanah pertanian berfungsi untuk menjaga kandungan bahan organik tanah dan sifat mikrobiologi tanah (Goyal et al., 2009).

82 | I Nengah Muliarta; Pengetahuan dan Persepsi Petani Terhadap.... 
Pengelolaan jerami padi dapat memberi nilai ekonomi bagi petani dan masyarakat lokal, serta dapat merangsang pertumbuhan ekonomi pedesaan yang lebih luas dengan memberi nilai tambah melalui pengembangan industri dan nilai tambah bagi lingkungan pertanian (Rosmiza et al., 2014b). Dalam sebuah penelitian di Malaysia disebutkan bahwa terdapat beberapa faktor yang mempengaruhi pemanfaatan jerami padi oleh petani. Faktor-faktor tersebut yaitu tidak adanya insentif bagi petani, teknologi yang tidak efisien, kurangnya fasilitas logistik (penyimpanan dan pengangkutan), rendahnya tingkat keterampilan dan pengetahuan petani, dan kurangnya modal untuk mengelola jerami (Rosmiza et al., 2014a).

Permasalahanya kemudian, apakah petani memiliki pengetahuan yang memadai untuk melakukan pengomposan jerami padi?. Kemudian, apakah petani mengetahui pentingnya memanfaatkan kompos jerami padi bagi ketersediaan hara tanah dan pertumbuhan tanaman? Pengetahuan petani terkait pengomposan jerami padi juga berhubungan dengan peran petugas penyuluh pertanian (PPL), sehingga menjadi penting juga mengetahui apakah PPL melakukan sosialisasi pengomposan jerami padi.

Penelitian ini bertujuan untuk meneliti tingkat pengetahuan petani dalam pengomposan jerami padi. Tujuan lainnya yaitu meneliti pengetahuan dan persepsi petani terhadap pentingnya pengomposan jerami padi. Penelitian juga bertujuan meneliti hubungan pengetahuan petani dan peran PPL dalam melakukan sosialisasi dan pelatihan pengomposan limbah jerami padi pada petani.

\title{
METODE PENELITIAN
}

\begin{abstract}
Alat dan Bahan
Alat penelitian yang diperlukan untuk survei adalah kuisioner dan alat perekam. Kuisioner yang digunakan dalam penelitian ini sebelumnya telah diujicobakan kepada anggota Kelompok Subak Manduang, Kecamatan Klungkung. Terdapat 15 poin pertanyaan yang diajukan kepada 13 orang petani yang ditemui di lapangan. Hasil uji validitas dengan tingkat signifikansi atau alpha sebesar 0,05 persen menunjukkan bahwa dari 15 pertanyaan terdapat 9 pertanyaan dinyatakan valid. Pertanyaan yang dinyatakan valid memiliki thitung antara 2,131 sampai 6,978, sedangkan t-tabelnya sebesar 1,796. Hasil uji reliabilitas menunjukkan bahwa nilai uji reliabilitas sebesar 0,845 atau berada diatas 0,60, sehingga instrumen dapat dikatakan reliabel (Latan, 2014).
\end{abstract}




\section{Pelaksanaan}

Survei dilakukan di 3 kecamatan (Banjarangkan, Klungkung, dan Dawan) di Klungkung selama Mei-Juni 2017. Wilayah Klungkung menjadi pilihan karena Klungkung merupakan salah satu wilayah yang masuk dalam program nasional pengembangan tanaman padi, jagung dan kedelai (Pajale). Dua kelompok Subak dipilih secara acak pada masing-masing kecamatan dan jumlah responden adalah 10 persen dari masing-masing anggota kelompok Subak (Arikunto, 2010). Kelompok Subak yang menjadi sampel penelitian disajikan dalam Tabel 1.

Tabel 1 Kelompok Subak yang menjadi sampel penelitian

\begin{tabular}{llcc}
\hline \multirow{2}{*}{ Kecamatan } & \multicolumn{1}{c}{ Kelompok Subak } & $\begin{array}{c}\text { Jumlah Petani } \\
\text { (orang) }\end{array}$ & $\begin{array}{c}\text { Jumlah } \\
\text { Responden (10\%) }\end{array}$ \\
\hline \multirow{2}{*}{ Klungkung } & Subak Gembalan & 170 & 17 \\
\cline { 2 - 4 } & Subak Jero Kuta & 110 & 11 \\
\hline \multirow{2}{*}{ Banjarangkan } & Subak Tegehan & 157 & 16 \\
\cline { 2 - 4 } & Subak Lepang & 154 & 15 \\
\hline \multirow{2}{*}{ Dawan } & Subak Pesinggahan & 186 & 19 \\
\cline { 2 - 4 } & Subak Sampalan Dlod Margi & 110 & 11 \\
\hline Total & & 887 & 89 \\
\hline
\end{tabular}

Sumber : Data jumlah petani diambil dari masing-masing kelompok Subak

Data pada penelitian survei yang berhasil dikumpulkan kemudian dianalisis secara deskriptif. Data selanjutnya ditabulasi dan ditampilkan dalam bentuk tabel dan persentase. Kuisioner yang digunakan sebelumnya telah diuji validitas dan uji reliabilitas. Pelaksanaan pengujian menggunakan software Microsoft excel 2010.

\section{HASIL DAN PEMBAHASAN}

\section{Karakteristik petani}

Jenis kelamin petani di Kabupaten Klungkung di dominasi oleh laki-laki, dimana dari 89 responden sebanyak 98,9 persen adalah petani laki-laki dan hanya $1,1 \%$ (1 orang) petani perempuan. Dominasi petani laki-laki juga terjadi di Filipina yang mencapai $92 \%$ dan di Vietnam mencapai $85 \%$. Dominasi ini menunjukkan bahwa petani laki-laki bertanggungjawab dalam budidaya padi sawah di Filipina dan Vietnam (Truc et al., 2012). Rendahnya jumlah perempuan yang terlibat langsung dalam pertanian juga terjadi di Borno-Nigeria yang hanya mencapai $1,88 \%$ dan salah satunya disebabkan oleh faktor budaya (MustafaMsukwa et al., 2011).

84 | I Nengah Muliarta; Pengetahuan dan Persepsi Petani Terhadap.... 
Umur petani di Kabupaten Klungkung 34,83 \% berada dalam rentang 41-50 tahun dan 32,58\% berada dalam rentang umur 51-60 tahun (Tabel 2). Data ini menggambarkan bahwa mayoritas responden masih energik dan pada usia produktif. Responden pada umur 61-70 dan 71-80 tahun tetap melakukan aktivitas bertani untuk mengisi waktu luang di usia senja dan aktivitas bertani dijadikan sarana kegiatan berolahraga sehingga tubuh tetap sehat.

\section{Tabel 2 Karakteristik Petani}

\begin{tabular}{|c|c|c|c|}
\hline No. & Kriteria & Jumlah (orang) & Persentase (\%) \\
\hline \multirow[t]{4}{*}{1.} & Jenis Kelamin & & \\
\hline & Laki-Laki & 88 & 98,90 \\
\hline & Perempuan & 1 & 1,10 \\
\hline & Total & 89 & 100,00 \\
\hline \multirow[t]{7}{*}{2.} & Umur (tahun) & & \\
\hline & $30-40$ & 15 & 16,85 \\
\hline & $41-50$ & 31 & 34,83 \\
\hline & $51-60$ & 29 & 32,58 \\
\hline & $61-70$ & 10 & 11,24 \\
\hline & $71-80$ & 4 & 4,50 \\
\hline & Total & 89 & 100,00 \\
\hline \multirow[t]{7}{*}{3.} & Pendidikan & & \\
\hline & Tidak tamat SD & 34 & 38,20 \\
\hline & SD & 26 & 29,21 \\
\hline & SMP & 4 & 4,50 \\
\hline & SMU & 21 & 23.60 \\
\hline & Perguruan Tinggi & 4 & 4.50 \\
\hline & Total & 89 & 100,00 \\
\hline \multirow[t]{9}{*}{4} & Pekerjaan & & \\
\hline & Petani & 73 & 82,02 \\
\hline & PNS & 3 & 3,37 \\
\hline & Wiraswasta & 3 & 3,37 \\
\hline & Pedagang & 6 & 6,74 \\
\hline & Sopir & 2 & 2,30 \\
\hline & Tukang Bangunan & 1 & 1,10 \\
\hline & Peternak Ayam & 1 & 1,10 \\
\hline & Total & 89 & 100,00 \\
\hline \multirow[t]{8}{*}{5} & Luas Lahan (are) & & \\
\hline & $1-20$ & 30 & 33,70 \\
\hline & $21-40$ & 32 & 35,96 \\
\hline & $41-60$ & 13 & 14,61 \\
\hline & $61-80$ & 6 & 6,74 \\
\hline & $81-100$ & 3 & 3,37 \\
\hline & $>1$ ha & 5 & 5,62 \\
\hline & Total & 89 & 100,00 \\
\hline
\end{tabular}


Terkait status pekerjaan responden teruangkap bahwa 82,02 persen petani di Kabupaten Klungkung merupakan petani penuh waktu. Sisanya merupakan pekerja paruh waktu yang memiliki pekerjaan utama seperti sebagai PNS (guru SD, Staf tata usaha SD dan staf pegawai Kominfo Klungkung), wiraswasta, pedagang, sopir, tukang bangunan dan peternak ayam. Hasil yang tidak jauh berbeda juga didapatkan Sjakir et al. (2015) dalam sebuah penelitian di Kabupaten Maros Sulawesi Selatan, dimana 93,4\% petani bekerja sebagai petani purna waktu.

\section{Pemanfaatan jerami oleh petani}

Petani di Kabupaten Klungkung dominan (69.66\%) memanfaatkan jerami padi sebagai mulsa, terutama saat petani menanam palawija (Tabel 3). Mulsa jerami padi dibutuhkan petani saat menanam palawija seperti kedelai, cabe, kacang panjang, timun, semangka, bunga dan sayur hijau. Hasil ini sama dengan pernyataan Rosmiza et al (2014b) yang menyatakan jerami padi secara umum digunakan sebagai mulsa saat menanam sayuran dan hortikultura. Pemanfaatan mulsa jerami padi dilakukan petani dengan beberapa alasan seperti untuk menekan pertumbuhan tanaman pengganggu, mengurangi penguapan dan mengurangi biaya pembelian mulsa plastik. Alasan petani tersebut sejalan dengan pandangan Coolong (2012) yang menyatakan mulsa jerami padi bermanfaat untuk pengendalian gulma dan dapat mengurangi biaya produksi. Menurut Khan Eusufzai et al. (2007), mulsa jerami padi meminimalkan penyusutan tanah dengan mengurangi penguapan dari permukaan tanah. Jerami padi dapat mengurangi kepadatan tanah dan meningkatkan daya serap air, meningkatkan porositas dan menurunkan bulk density.

\section{Tabel 3. Pemanfaatan/pengelolaan jerami padi oleh petani}

\begin{tabular}{lc}
\hline \multicolumn{1}{c}{ Pemanfaatan/pengelolaan Jerami padi } & Persentase (\%) \\
\hline Pakan ternak & 0,00 \\
Pembenaman & 0,00 \\
Pupuk Organik (Pengomposan) & 0,00 \\
Mulsa & 69,66 \\
Pembakaran & 30,34 \\
\hline Total & 100,00 \\
\hline
\end{tabular}

Sumber : Hasil survei yang telah diolah

Terdapat sekitar 30,34\% (27 petani) yang membakar jerami padi yang dihasilkan dengan alasan untuk mempercepat pengolahan lahan dan membahasmi hama. Terdapat pula petani yang membakar jerami karena berdasarkan pengetahuan yang didapatkan bahwa abu pembakaran jerami padi dapat bermanfaat bagi kesuburan tanah. Pembakaran jerami padi merupakan 
salah satu awal penerapan pertanian organik yang berasal dari pengalaman petani (Dobermann \& Fairhurst, 2002).

Petani berasumsi bahwa abu dari pembakaran jerami padi dapat meningkatkan produksi jagung dan kacang tanah. Pandangan ini sejalan dengan pandangan Ahmed \& Ahmad (2013) yang menyatakan banyak petani berpemikiran bahwa residu pembakaran meningkatkan kesehatan tanah dan hasil panen. Kemampuan teknis petani tampaknya tidak berdampak pada keputusan untuk membakar residu padi. Hasil ini memiliki implikasi penting bagi kebijakan mitigasi untuk mengurangi pembakaran residu (Gupta, 2010).

Petani di Kabupaten Klungkung tidak ada yang memanfaatkan limbah jerami padi sebagai kompos. Mayoritas $(97,75 \%)$ menyatakan tidak tahu cara atau metode pengomposan jerami padi dan hanya 2,25\% yang mengaku sedikit tahu cara pengomposan jerami padi. Secara umum petani $(96,63 \%)$ tidak tahu bahwa dalam pengomposan memerlukan dekomposer dan 96,63\% petani juga tidak tahu bahwa dekomposer berfungsi untuk mempercepat pengomposan. Hasil ini sejalan dengan pemikiran Supaporn et al. (2013), bahwa prosedur pembuatan kompos jerami padi yang kompleks dan padat karya menyebabkan petani kesulitan dalam pembuatan kompos jerami padi.

\section{Pengetahuan dan persepsi petani terhadap pengomposan jerami padi}

Petani umumnya $(73,03 \%)$ berpendapat bahwa jerami padi tidak perlu dikomposkan dan hanya 2,25\% yang menyatakan jerami padi sangat perlu dikomposkan. Mayoritas petani berpandangan jerami padi tidak perlu dikomposkan karena sudah dimanfaatkan sebagai mulsa. Gambaran terkait persepsi petani mengenai perlu-tidaknya jerami padi di komposkan disajikan dalam Gambar 1.

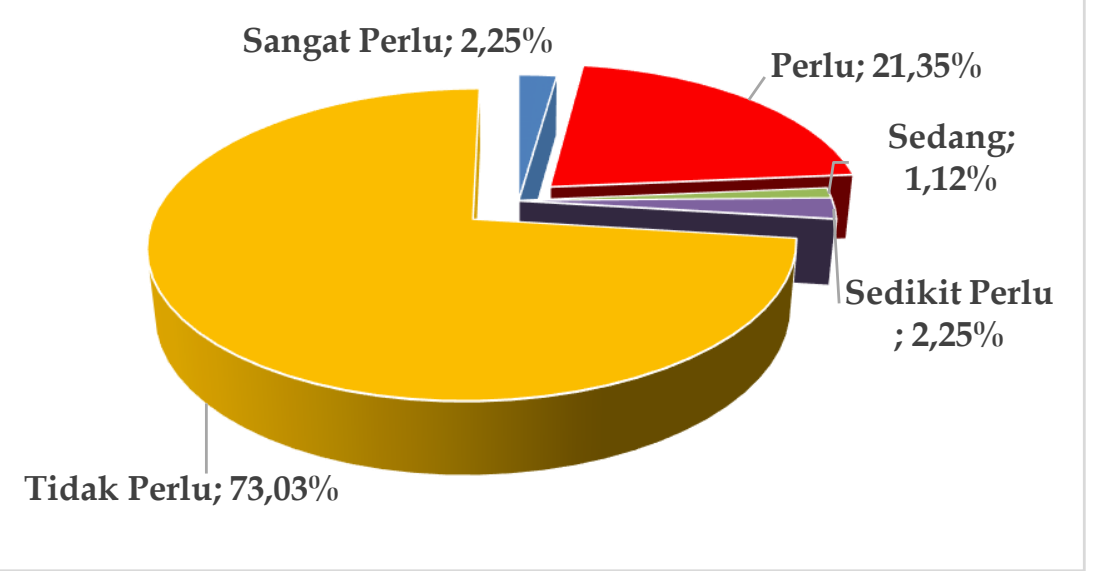

Gambar 1.

Persepsi petani terkait perlu-tidaknya pengomposan jerami padi 
Sebanyak $74,16 \%$ petani tidak mengetahui jika jerami padi dapat dikomposkan. Tercatat hanya $13,48 \%$ yang mengaku tahu jerami padi dapat dikomposkan dan 12,36\% menyatakan sedikit tahu. Menurut Sardjono et al. (2012), pengetahuan petani merupakan faktor utama dalam pemanfaatan dan pengolahan limbah jerami menjadi pupuk organik. Pengetahuan adalah prasyarat penting yang mempengaruhi keputusan petani dalam mengadopsi teknologi pengomposan,sehingga peran dari penyuluh dalam mempromosikan teknologi pupuk kompos menjadi sangat penting (Mustafa-Msukwa et al., 2011).

Hasil wawancara terhadap 12 orang petugas penyuluh lapangan (PPL) di Kabupaten Klungkung menunjukkan hasil bahwa $100 \%$ tidak pernah melakukan sosialisasi pengomposan jerami padi. Tercatat $58.33 \%$ (7 orang) PPL beberapa kali melakukan sosialisasi pengomposan dan sebanyak 16.67\% (2 orang) satu kali melakukan sosialisasi pengomposan, tetapi melakukan sosialisasi pengomposan dengan bahan kotoran sapi. Sementara 25\% (3 orang) mengakui sama sekali tidak pernah melakukan sosialisasi pengomposan. Penyuluh lapangan pada dasarnya memegang peran utama dalam upaya mempopulerkan teknologi pengomposan di kalangan petani (Singh \& Nain, 2014).

Dominan $(78,65 \%)$ petani tidak tahu bahwa jerami padi harus dikembalikan ke tanah dalam bentuk kompos. Sekitar $82 \%$ petani juga tidak tahu bahwa penggunaan kompos jerami padi dapat mengurangi penggunaan pupuk anorganik. Secara umum, petani memiliki tingkat pengetahuan yang rendah terhadap manfaat jerami padi. Petani juga kurang mendapatkan informasi tentang perkembangan penggunaan jerami padi yang dapat memberi manfaat secara sosial dan ekonomi bagi petani (Rosmiza et al., 2014b). Jerami padi memiliki potensi ekonomi yang sangat besar bagi petani, tetapi akibat kurangnya kesadaran untuk mengembangkan alternatif pemanfaatan jerami padi telah menyebabkan turunnya manfaat ekonomi yang di dapatkan (Roy \& Kaur, 2015). Sebagian besar petani belum menyadari akan potensi limbah pertanian dan belum menyadari bahwa limbah pertanian dapat dijadikan bahan baku yang menguntungkan untuk berbagai industri (Verma, 2014).

Terdapat $40,45 \%$ petani yang tidak mengetahui bahwa kompos jerami padi bermanfaat bagi kesuburan tanah dan $26,97 \%$ yang menyatakan tahu serta $32,58 \%$ yang menyatakan sedikit tahu bahwa kompos jerami padi bermanfaat bagi kesuburan tanah. Pengetahuan petani mengenai manfaat kompos jerami bagi kesuburan tanah juga dipengaruhi oleh tingkat pendidikan (Gambar 2). 


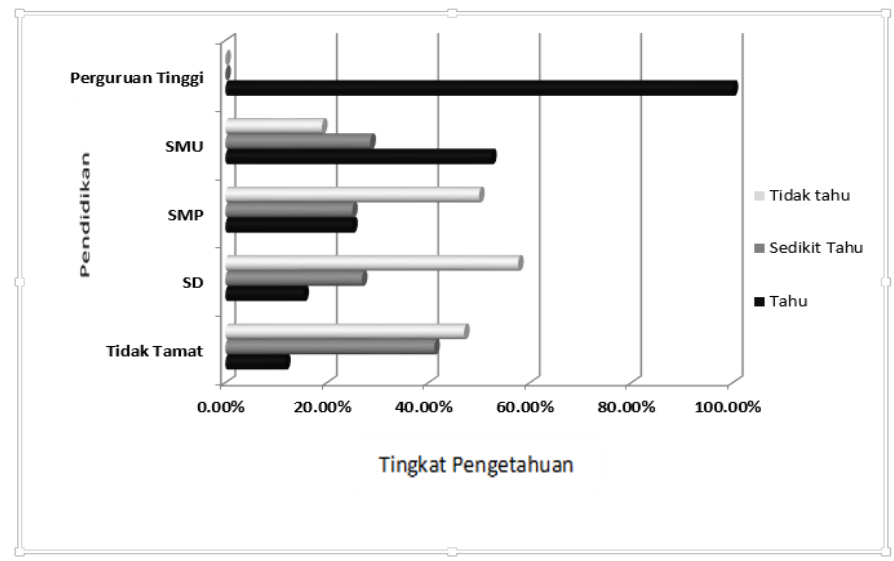

Gambar 2.

Tingkat pengetahuan petani mengenai manfaat kompos terhadap kesuburan tanah dilihat dari tingkat pendidikan.

Pengetahuan petani tentang manfaat kompos jerami padi bagi kesuburan tanah cenderung didapatkan dari cerita sesama petani atau selama menempuh pendidikan formal dan bukan dari pengalaman sendiri. Survei mendapatkan bahwa $68,54 \%$ petani tidak mengetahui kompos jerami padi mengandung unsur hara yang dibutuhkan tanaman, hanya sekitar $17,98 \%$ petani yang mengetahui dan $13,48 \%$ petani yang sedikit mengetahui bahwa kompos jerami padi mengandung unsur hara yang dibutuhkan tanaman. Akibat ketidaktahuan terhadap kandungan unsur hara jerami padi jika dijadikan pupuk menyebabkan petani di Sri Lanka membuang jerami padi (Amamsiri \& Wichramasinghe, 1977). Tingkat pengetahuan petani mengenai kandungan unsur hara jerami dilihat dari tingkat pendidikan petani disajikan dalam Gambar 3.

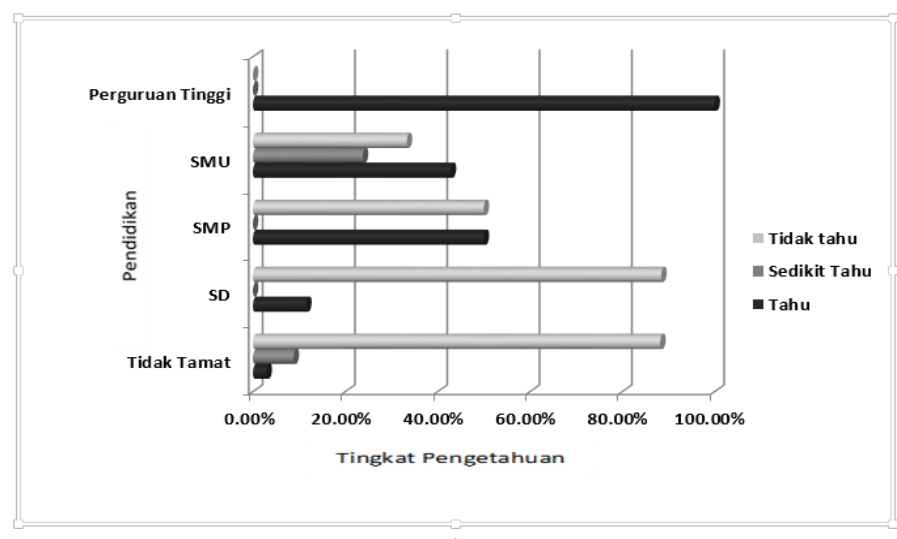

Gambar 3.

Tingkat pengetahuan petani mengenai kandungan unsur hara jerami dilihat dari tingkat pendidikan petani 
Umumnya petani $(74,16 \%)$ mengakui bahwa tidak mengetahui jika pembakaran jerami padi berdampak pada peningkatan emisi karbon, hanya $16,85 \%$ yang menyatakan mengetahui dan $8,99 \%$ yang menyatakan sedikit mengetahui. Redahnya tingkat pengetahuan petani terhadap dampak emisi karbon dari pembakaran jerami padi sejalan dengan pendapat Grover et al. (2015). Selain tidak mengetahui dampak pembakaran jerami terhadap polusi udara, petani juga tidak menyadari dampak pembakaran jerami padi terhadap penurunan kualitas tanah. Membakar satu ton jerami dapat menghasilkan sekitar $3 \mathrm{~kg}$ bahan partikulat, $60 \mathrm{~kg}$ karbon monoksida, $1.460 \mathrm{~kg}$ karbondioksida, $199 \mathrm{~kg}$ debu dan $2 \mathrm{~kg}$ sulfur dioksida (Gupta et al., 2004). Tingkat pengetahuan petani mengenai dampak pembakaran jerami padi terhadap peningkatan emisi karbon dilihat dari tingkat pendidikan petani disajikan dalam Gambar 4.

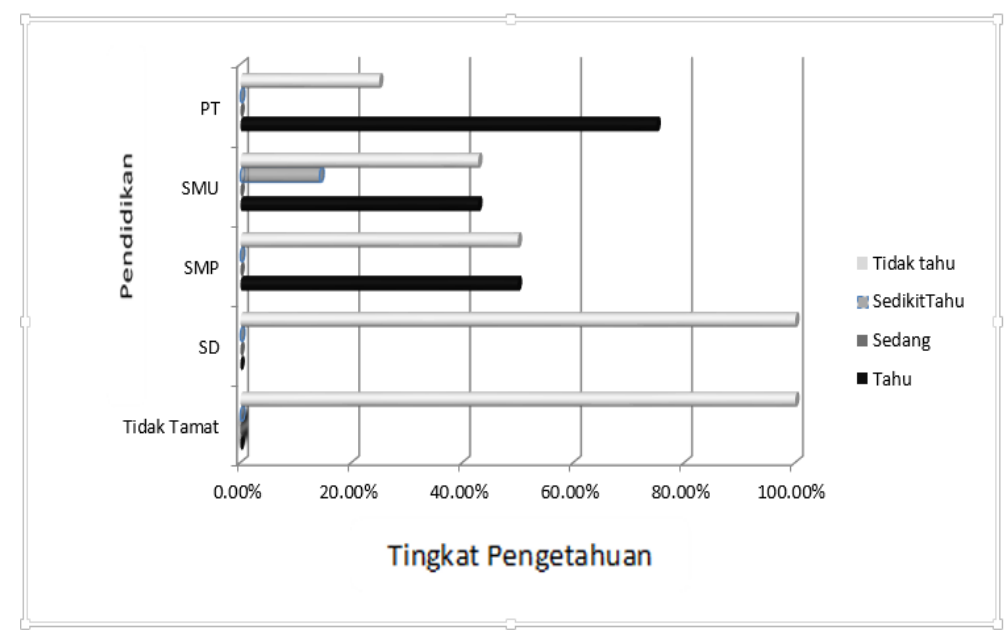

Gambar 4.

Tingkat pengetahuan petani mengenai dampak pembakaran jerami padi terhadap peningkatan emisi karbon dilihat dari tingkat pendidikan petani

Menurut Sherawat \& Sindhu (2012), terdapat perbedaan yang cukup besar antara kesadaran dan upaya pemanfaatan limbah pertanian oleh petani. Perbedaan ini terjadi karena kurangnya pelatihan, ceramah dan demonstrasi teknik pengolahan limbah pertanian di lapangan. Berdasarkan hasil penelitian terungkap dari 89 responden tercatat $97,75 \%$ belum pernah mengikuti pelatihan pengomposan jerami padi, hanya 2,25\% (2 orang) yang mengaku pernah dan hanya sekali mengikuti pelatihan pengomposan jerami padi. Sayangnya pelatihan yang didapatkan tidak pernah dipraktekkan untuk melakukan pengomposan jerami padi.

Menurut pengakuan para petani hambatan utama pengomposan jerami padi adalah tidak mengetahui cara atau metode pengomposan jerami padi. Pengetahuan tentang teknik pengomposan cepat menjadi salah satu faktor yang 
mempengaruhi adopsi teknologi pengomposan (Truc et al., 2012). Hambatan kedua dalam pengomposan jerami menurut petani adalah keterbatasan tenaga kerja yang membantu dalam pengomposan. Walaupun rata-rata jumlah anggota keluarga petani 3-5 orang, namun yang membantu dalam bertani rata-rata hanya 1 orang. Menurut Supaporn et al. (2013), untuk melakukan pengomposan petani memerlukan tenaga kerja tambahan dan biaya tambahan, karena proses pengomposan jerami padi selain memang rumit juga padat karya. Hambatan ketiga yang dialami petani dalam pengomposan jerami padi yaitu keterbatasan waktu, karena selain bertani, petani di Klungkung juga terlibat dalam kegiatan adat yang menyebabkan waktu untuk melakukan pengomposan terbatas. Belum lagi petani harus segera mempersiapkan lahan untuk mengejar masa tanam berikutnya. Singh \& Nain (2014) berpendapat kesulitan pemanfaatan dan pengomposan jerami padi selain disebabkan oleh keterbatasan waktu juga keterbatasan jumlah tenaga yang membantu, serta perlu persiapan ekstra. Kasus di Thailand diketahui terdapat beberapa faktor yang mempengaruhi keputusan petani untuk melakukan pengomposan jerami padi. Faktor-faktor tersebut seperti tingkat pendidikan, frekuensi pelatihan pengomposan jerami padi, pengetahuan dan teknologi, serta keterbatasan tenaga kerja (Supaporn et al., 2013).

\section{Simpulan}

Umumnya petani $(97,75 \%)$ tidak mengetahui cara pengomposan jerami padi, karena tidak pernah mendapatkan sosialisasi pengomposan jerami padi dari petugas penyuluj lapangan (PPL). Jumlah petani yang mendapatkan pelatihan sangat terbatas $(2,25 \%)$ dan hanya mendapatkan pelatihan sebanyak satu kali, serta enggan mengimplementasikan ilmu yang didapatkan.

Petani cenderung $(74,16 \%)$ berpandangan jika jerami padi tidak dapat dikomposkan. Hal ini menunjukkan bila jerami padi selama ini belum dipandang sebagai bahan pupuk oleh sebagian besar petani, buktinya terdapat $84,27 \%$ petani yang menyatakan tidak mengetahui bahwa membakar jerami padi berarti membuang bahan pupuk organik.

Rendahnya pengetahuan petani mengenai cara pengomposan jerami padi dan manfaat jerami padi bagi kesuburan tanah erat kaitannya dengan rendahnya sosialisasi pemanfaatan jerami padi dan teknik pengomposan jerami padi yang efektif, efisien serta cepat. Petani membutuhkan teknologi pengomposan yang mudah, cepat dan menghasilkan kualitas kompos yang baik.

\section{Saran}

Kedepan Dinas Pertanian melalui petugas penyuluh lapangan harus lebih gencar untuk melakukan sosialisasi dan pelatihan pengomposan jerami padi. Pemanfaatan jerami padi secara optimal melalui pengomposan selain akan mengurangi penggunaan pupuk anorganik, juga memberi kontribusi bagi 
pengurangan pencemaran lingkungan dan menjadi jalan mewujudkan budidaya padi yang ramah lingkungan.

\section{DAFTAR PUSTAKA}

Afriani, H., Dianita, R., \& Idris, N. (2013). Optimalisasi Pemanfaatan Limbah Pertanian Melalui Pembuatan Kompos dan Silase Pada Kelompok Peternak Sapi dan Kelompok Wanita Petani Holtikultura. Jurnal Pengabdian Pada Masyarakat, 55(1), 21.

Ahmed, T., \& Ahmad, B. (2013). Why do farmers burn rice residue? : examining farmers' choices in Punjab, Pakistan. Punjab.

Amamsiri, S. ., \& Wichramasinghe, K. (1977). Use of Rice Straw as a Fertilizer Material. Tropical Agriculturist, 133, 39-49.

Arikunto, S. (2010). Prosedur Penelitian : Suatu Pendekatan Praktik (Edisi Revi). Jakarta: Rineka Cipta.

Binod, P., Sindhu, R., Singhania, R. R., Vikram, S., Devi, L., Nagalakshmi, S., ... Pandey, A. (2010). Bioethanol production from rice straw: An overview. Bioresource Technology, 101(13), 4767-4774. https://doi.org/10.1016/j.biortech.2009.10.079

Chang, C. H., Liu, C. C., \& Tseng, P. Y. (2013). Emissions inventory for rice straw open burning in Taiwan based on burned area classification and mapping using Formosat-2 satellite imagery. Aerosol and Air Quality Research, 13(2), 474-487. https://doi.org/10.4209/aaqr.2012.06.0150

Coolong, T. (2012). Mulches for Weed Management in Vegetable Production. In Vegetable Production. In: A. Price (ed.). Weed Control. (pp. 57-74). Retrieved from www.intechopen.com

Dobermann, A., \& Fairhurst, T. H. (2002). Rice Straw Management. In Better Crops International (Vol. 16).

Golabi, M. ., Denney, M. ., \& Iyekar, C. (2004). Use of Composted Organic Wastes As Alternative to Synthetic Fertilizers for Enhancing Crop Productivity and Agricultural Sustainability on The Tropical Island of Guam. Conserving Soil and Water for Society: Sharing Solutions. ISCO 2004 - 13th International Soil Conservation Organisation Conference, (234), 1-6. Brisbane.: International Soil Conservation Organisation.

Goyal, S., Singh, D., Suneja, S., \& Kapoor, K. . (2009). Effect Of Rice Straw Compost On Soil Microbiological Properties And Yield Of Rice. Indian Journal Of Agricultural Research, 43(4), 263-268.

Grover, D., Kaur, P., \& Sharma, H. . (2015). Possible reasons and farmers awareness towards crop residue burning: an overview and a case study from Mirzapur village of Kurukshetra district, India. Environment $\mathcal{E}$ We an International Journal of Science \& Technology (EWIJST), 10(2015), 75-85.

Gupta, P. K., Sahai, S., Singh, N., Dixit, C. K., Singh, D. P., Sharma, C., ... Garg, S. C. (2004). Residue burning in rice-wheat cropping system: Causes and

92 | I Nengah Muliarta; Pengetahuan dan Persepsi Petani Terhadap.... 
implications. Tanzania. Afr. J. Ecol, 87(12), 1713-1717.

Gupta, R. (2010). The Economic Causes Of Crop Residue Burning in Western IndoGangetic Plains *. New Delhi.

Khan EUSUFZAI, M., Maeda, T., \& Fujii, K. (2007). Field Evaluation of Compost, Sawdust and Rice Straw Biomass on Soil Physical and Hydraulic Properties. Journal of The Japanese Society of Soil Physic, 107, 3-16.

Latan, H. (2014). Aplikasi Analisis Data Statistik untuk Ilmu Sosial Sains Dengan STATA (Cetakan Ke-1). Bandung: Penerbit Alfabeta.

Mustafa-Msukwa, A. ., Mutimba, J., Masangano, C., \& Edriss, A. . (2011). An Assessment of the Adoption of Compost Manure by Smallholder Farmers in Balaka District, Malawi (Vol. 39). Malawi.

Pavithira, E., Sirisena, D. N., \& Herath, H. M. S. K. (2017). Effect of Potassium Fertilizer Split Applications together with Straw on Optimum Level in Leaf and Stem of Rice. Journal of Agricultural Sciences, 12(1), 24. https:// doi.org/10.4038/jas.v12i1.8203

Rashad, F. M., Kesba, H. H., Saleh, W. D., \& Moselhy, M. A. (2011). Impact of rice straw composts on microbial population, plant growth, nutrient uptake and root-knot nematode under greenhouse conditions. African Journal of Agricultural Research, 6(5), 1188-1203. https://doi.org/10.5897/AJAR10.986

Rosmiza, M. ., Davies, W. ., Rosniza, A. C. ., Mazdi, M., Jabil, M. ., Wan-Toren, W. ., \& CheRosmawati, C. . (2014a). Farmers' Participation in Rice StrawUtilisation in the MADA Region of Kedah, Malaysia. Mediterranean Journal of Social Sciences, 5(23), 229-237. https://doi.org/10.5901/mjss.2014.v5n23p229

Rosmiza, M. ., Davies, W. ., Rosniza, A. C. ., Mazdi, M., \& Jabil, M. . (2014b). Farmers' knowledge on potential uses of rice straw: An assessment in MADA and Sekinchan, Malaysia. Malaysian Journal of Society and Spac, 10(5), 30-43.

Roy, P., \& Kaur, M. (2015). Status and Problems of Paddy Straw Management in

West Bengal. International Journal of Advances in Agricultural and Environmental Engineering (IJAAEE), 2(1), 44-48. https://doi.org/10.15242/ijaaee.er1015204

Sardjono, N., Susilo, B., \& Wignyanto. (2012). Strategi Pengembangan Sistem Produksi Pupuk Organik Pada Unit Pengolahan Pupuk Organik (UPPO) di Desa Bangunsari Kabupaten Ciamis. Jurnal Teknologi Pertanian, 13(2), 138-148.

Sherawat, P.S., Sindhu, N. (2012). Agricultural Waste Utilization for Healthy Environment and Sustainable Lifestyle. Third International Scientific Symposium "AgrosymJahorina 2012, 393-399. Third International Scientific Symposium “AgrosymJahorina 2012."

Singh, S., \& Nain, L. (2014). Microorganisms in the Conversion of Agricultural Wastes to Compost. Proceedings of the Indian National Science Academy, 80(2), 473-481. https://doi.org/10.16943/ptinsa/2014/v80i2/7 
Sjakir, M., Awang, A. H., Azima, A. M., Hussain, M. Y., \& Zaimah, R. (2015). Learning and Technology Adoption Impacts on Farmer's Productivity. Mediterranean Journal of Social Sciences, 6(4). https://doi.org/10.5901/mjss.2015.v6n4s3p126

Supaporn, P., Kobayashi, T., \& Supawadee, C. (2013). Factors affecting farmers' decisions on utilization of rice straw compost in Northeastern Thailand. Journal of Agriculture and Rural Development in the Tropics and Subtropics, 114(1), 21-27.

Tipayarom, D., \& Oanh, N. T. K. (2007). Effects from Open Rice Straw Burning Emission on Air Quality in the Bangkok Metropolitan Region. ScienceAsia, 33(3), 339-345. https://doi.org/10.2306/scienceasia1513-1874.2007.33.339

Truc, N. T. ., Sumalde, Z. ., Espaldon, M. V. ., Pacardo, E. ., Rapera, C. ., \& Palis, F. . (2012). Farmers' Awareness and Factors Affecting Adoption of Rapid Composting in Mekong Delta, Vietnam and Central Luzon, Philippines. Journal of Environmental Science and Management, 15(2), 59-73.

Verma, S. S. (2014). Technologies for Stubble Use. Journal of Agriculture and Life Sciences, 1(2), 106-110. Retrieved from www.jalsnet.com

Zhao, H., Yu, H., Yuan, X., Piao, R., Li, H., Wang, X., \& Cui, Z. (2015). Degradation of Lignocelluloses in Rice Straw by BMC-9, a Composite Microbial System. Journal of Microbiology and Biotechnology, 24(5), 585-591. https://doi.org/10.4014/jmb.1509.09043 